\title{
The Values of Local Wisdom in Dedeng: a Vocal Tradition of Malay Langkat Community
}

\author{
${ }^{1}$ Koko Sujatmoko \\ Universitas Sumatera Utara \\ E- mail: Ricovaslah.moko@yahoo.com \\ ${ }^{2}$ Niza Ayuningtias \\ Universitas Sumatera Utara \\ E- mail: nizaayuningtias@yahoo.com
}

\begin{abstract}
This research describes Dedeng as local vocal tradition of Malay Langkat community in the province of North Sumatra Indonesia along with its values and local wisdom embedded in it. The values, hopefuly can be used as guiding lines for young generation to build their character and live a better life based on values of vocal tradition Dedeng. Method: This research used qualitative research method. The data obtained through interviewing selected ethnic and religious groups communities and Focus Group Discussion (FGD). Finding: This research shows that Dedeng as local vocal tradition of Malay Langkat Community contains the values of respect to universe, environmental care, social interaction, respect for women and social mutual cooperation.
\end{abstract}

Keywords: Dedeng, vocal tradition, local wisdom, value, Malay Langkat.

\section{INTRODUCTION}

Indonesia has 746 local languages. If every local language is owned by one ethnic,it means there are 746 ethnic communities in Indonesia. Each ethnic with its language and culture has a potentiality to be the basis for creative industry development.

Since 2006, Indonesia has started the development of creative economy, as instructed by the then President SusiloBambangYudhoyono (SBY). The instruction was followed up by the Ministry of Trade by mapping the contribution of Indonesia's creative industries.Then in 2008, the blueprint of fourteen Indonesian creative industry sub-sectors was launched, namely(1) advertising, (2) architecture, (3) marketing artistic goods, (4) crafts, (5) design, (6) fashion, 7) video, film, and photography, (8) interactive games, (9) music, (10) art performance, (11) publishing and printing, (12) computer and software services, (13) television and radio; and (14) research and development on creative industry. Finally, the year of 2009 was commemorated as the year of creative industry.

In North Sumatra, where the population is heterogeneous, various cultural attractions are held annually in various regions in order to support the sector of tourism. Among these are the Pekan Budaya Melayu (Malay Cultural Week), the Great Malay Cultural Festival, the Flower Festival in Tanah Karo, the Yahowu Festival in Nias Island, the Lake Toba Festival, the Rondang Bittang Festival, and etc. Thus, cultural art is a primary means of cultural transmission and preservation. In addition, it may also become the economic basis for society.Therefore, the preservation of art and culture has become a necessity for people around the world. The cultural arts discussed here are the ones that are rooted from traditionalor local values.

The state, since the government of President SBY, has given opportunities to develop creative industries in Indonesia. In his campaign, the current 
President Joko Widodo also has expressed his admiration for the creativity of young people in producing creative products primarily by utilizing digital technology, such as music, movies and games. Then, it was followed up by President Joko Widodo by inaugurating the formation of Creative Economy Agency of Republic of Indonesia on January $26^{\text {th }}$, 2015. One that was under the Ministry of Tourism and Creative Industries of Republic of Indonesia. The function of the agency is to accommodate the aspirations of musicians and those who engaged in creative industries.

Spaces that are opened, on the one hand, have become opportunities for the community of creative industry. On the other hand, however, the relationships between actors, inindustry, investors, governments, and markets allow the domination of one element over another. Another possibility is the exploitation of exiting cultural potential without any creative development efforts. If it happens, the culture will stagnate.

Local cultures have potential to be developed into a creative industry. It can become a media to introduce the ethnic culture of Indonesia to the people, especially young generation so that they know, admire, appreciate, have a sense of belonging, and be more familiar with their natural environment, social, and culture.

Indonesia is a country of distinctiveness. It is not only unique in terms of location and geographical composition, but also in its culture. The location of Indonesia along the equator and archipelago make Indonesia a country in the world trajectory and at the same time it makes the sea a unifying media of its nation. With such geographical composition, it is easier for foreign cultures to enter Indonesia. The spread of the population in over 17,000 islands creates patterns of dissemination and different cultural systems of its society, one of which is the tradition of Malay Langkat.

Langkat Regency is a region that belongs to Malay ethnic culture located in the East Coast of North Sumatera. Culturally, the ethnic of Malay Langkat has varieties of custom and cultures including arts,such as Malay Ronggeng, Senandung (Hum), Hadrah, Barzanji, Inai (dance music for brides), Serampang XII dance and also vocal tradition called Dedeng. Dedeng was originally sung during the agricultural and maritime customary activities (Takari: 56, 1996), namely in the ceremony of cutting down the trees for new agricultural land, seeds plantation, harvesting, and fishing activities.

In terms of context, Dedeng can be categorized as sacred and religious songs, because for local people this singing activity was initially considered sacred and performed for the supernatural spirits (Takari: 55, 1996). According to Takari, Dedeng is categorized as part of an animism.

Dedeng means singing, or a singing activity of a person or community group aimed at providing a protection, fertility, and abundant products in agriculture. Although Dedeng refers to singing activities, it does not mean singing in a general sense like any other Malay musical cultures such as Malay Dendang and Malay Langgam. Malay Dendang emphasizes more on its function as an ordinary entertainment, while Dedeng is conducted for a more meaningful and special activity which is singing to hope getting abundant agricultural products from supernatural powers that are believed to be able to give protection from crops enemies; such as plant pests, wild animals, and also invisible plant pests. It certainly has a close relationship to the local wisdom of Malay Langkat community.

The local wisdom certainly did not occur accidently, but they took a long time to finally prove that it is good for their lives. It makes local wisdom a traditional culture that firmly attached to people's lives. However, its values begin to fade and lose their substantive meaning from time to time. Then, the only thing left is the surface, that becomes a meaningless symbol. Even recently the culture of society almost reduces entirely and it merely, manifests itself as a display of formality. Its presence is only for commercialization and profits.

Many factors cause local wisdom and culture in general losing its strength. In addition to the lack of ability of the community in creatively and contextually interpreting their local wisdom, other factors are due to the flow of globalization and subjective interests of some community elites.

Then cultural disasters begin to germinate in society. Under these circumstances, people are not capable to see, even to solve their problems wisely. Those crises become a part of the nation's life.

The magical phenomenon in human life is the first stage of human cultural development. This was stated by C.A. Van Peursen, as translated by Dick Hartoko (1976: 18) who divides the stage of human life into three stages, namely the mystical stage, ontological stage and functional stage. The mystical stage is the stage where people live with a life full of magical beliefs and myths in the form of stories guided by a group of people. Humans at this stage are classified as the ones who intensively communicate with the spirit realm and mythology. At this stage, according to Van Peursen, they feel that they are surrounded by supernatural forces. From his statement, it is clearly in accordance with what happens during the activities of Dedeng. Based on the facts, the aims of Dedeng is to communicate with the spirit realm both in the form of human or spirits from 
nature. It is also a medium of communication with surrounded supernatural forces and also contains the mythological elements of wild animals that are believed to protect the ethnic of Malay Langkat community.

The characteristics of magic found in Dedeng indicate that this song is an old vocal tradition. Based on some sources, it is explained that Malay culture in its developmental phase has surpassed several stages of development starting from the Age of Animism, Hinduism, the influence of Buddhist Culture, Islamic Culture (Arabic), and Portuguese Culture ( Zulfahmi, 2008: 66).

Based on the previous explanation, the research of society traditions, especially Malay Langkat community is necessary to avoid the extinction of local wisdom values and to maintain them as media of learning and character building of the nation. Therefore it is necessary to conduct a research on the Dedeng tradition found in the Malay Langkat community.

In general, local wisdom can be understood as local ideas that are wise, full of wisdom, good values, embedded and followed by community. Ridwan (2007) stated that local wisdom can be understood by human using their mind (cognition) in order to act and behave toward something such as objects or events occured in a particular circumstance.

The previous definition was arranged etymologically, in which wisdom is understood as the ability of a person in using his or her mind to act or behave as a result of his or her judgment on something, either object or event occured. As a term, it involves patterns of relationship between human and humans or humans and their physical environment. The pattern of interaction that has been designed is called settting. Setting is an interaction space in which one can construct face-to-face relationships within the environment. A setting of life that has been formed will directly produce values. These values will become the basis of their relationship or a reference to their behavior.

Ahimsa-Putra (2008: 12) declared that local wisdom can be defined as a set of knowledge and good practices derived both from previous generations and from experiences that are related to environment and other communities, which are used to solve the problems or difficulties properly and correctly.

While, Jim Ife (2002) stated that local wisdom is values which are created, developed and maintained in local community due to their ability to survive, and become a life guide for people. Local wisdom includes mechanisms and ways to act and behave as outlined in social order.
Local wisdom is all local intelligences which are transformed into invention, work and initiative so that people can be independent in their ever-changing social climate. These ideas, work and initiative are also called culture. Culture is not a new term. Culture defined as all the thoughts, behaviors, actions, and attitudes that people do every day. According to Koentjaraningrat (in Rustanto, 2005), culture or in English known as "Institutionalization" is a learning process that everyone passes during their life to adapt their mind and attitudes to customs, system of norms and all the rules of culture and society.

In general, local wisdom is considered as a life perspective, science and various life strategies in the form of activities conducted by local communities in order to solve various problems faced in fulfilling their needs. It is not only the traditional values or local characteristics but it is also the beneficial values that can be used to realize the expectations or values that are also universally craved by humans. Thus it can be concluded that local wisdom is a set of knowledge, values, behavior, and how to behave towards certain objects and events in the environment that is recognized by the community to be the goodness or truth.

This research is conducted to answer two research questions formulated as its baseline, namely, how Dedeng tradition runs in Malay Langkat community? and what are the values of local wisdom found in Dedeng tradition?

\section{METHOD}

To do the research, it is necessary to note down points that are related to Dedeng and the values embedded in it and regarded as local wisdom.

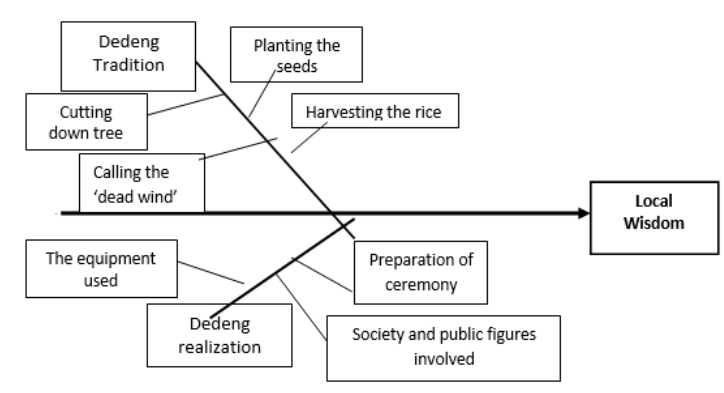

Fig. 1 Flow Chart

Qualitative method is used in this research. Spradley (1997) stated that it is more appropriate to use qualitative research in studying culture and behavior in social condition. This research attempts 
to describe people's behaviors and actions in Dedeng traditional ceremonies. Technique of snowball sampling is used in data collection by conducting observation and interview.

In the process of data collection, three main steps were conducted, namely (1) conducting a general observation to obtain a description of sociocultural situation that becomes the object of research; (2) conducting focused observations to obtain a more detailed description of elements and components previously found in general observation; (3) selecting components or aspects that become the priority of research.

Interviews were conducted with informants that came from various ethnic groups. It was conducted individually or by doing focus group discussions either in the house or in the determined places. Data then described and analysed descriptively.

\section{RESULT AND DISCUSSION}

\section{A. The Origin of Dedeng}

Until now there has been no historical evidence of when Dedeng vocal tradition started to be sung. However, based on its usage in Langkat Malay ethnic culture, it can be identified that this vocal tradition began to be used by Malay ethnic society in the era of animism. The animistic features of this song can be seen based on its texts which is addressed to supernatural spirits surrounding their neighborhoods, which at that time were believed can provide them protection.

Based on the information from some informants, there are some differences about the history of Dedeng. However, from all the informatiions gathered it is concluded that Dedeng was derived from the story or legend of a young man named Dedeng / Deden who was legendary around Langkat coast such as Kuala Serapuh, Kampai Island and Tapak Kuda Island.

In addition, Dedeng is almost entirely poured in the form of pantun (people poems, advice poems, love poems, funny poems, and aphorism poems). It also contains the expressions of soul / feelings / lusts of heart due to grief (sorrow), an outlet (complaint / request to the inhabitants of nature ), especially to the Almighty (in the form of praying ritual), sung by people while walking down to the location of rice fields, and is also sung in rice harvesting season (in Langkat known as Berahoi). The same things also occur among the coastal Malay people who are facing the waves and storms in order to earn a living and income from the open seas, and the ones who earn a living from the forest crop (honey). It is also used as fairy tales before bed (known as Daduh / Dadung rhythm).

\section{B. The Understanding of Dedeng}

Dedeng in the culture of Malay Langkat ethnic defined as singing or vocal tradition sung by a person or group of people with the aim to expect, to beg or to ask. According to some informants, Dedeng is not an ordinary vocal traditio, it is a type of vocal tradition that contains magical elements.

Magical elements of dedeng can be seen from the text that has the characteristics of animism since the texts presented by the singers are intended to invoke the protection from supernatural powers and humans who act evil. Moreover, the song is sung for hoping to gain the protection from the enemies of human. These enemies can be human beings themselves, beasts, pests and forces of supernatural around the neighborhood which are believed may bring harm to humans.

\section{The Function of Dedeng}

Soedarsono (2002: 118) said that the function of performing arts in general is basically divided into 3 namely, (1) art as a means of ritual, (2) art as a means of personal entertainment, and (3) art as an aesthetic presentation. Based on the context of Dedeng, it can be seen that the main function of Dedeng is as a means to carry out a ceremonial activity that is considered sacred due to its purpose of getting protection from supernatural powers around the farmland. It also aims to get protection in the sea for fishermen from supernatural beings whether they are seen or unseen, including sacred wild beasts such as tigers, bees, and snakes and the storm wind for fishermen. According to an informant, in his time tiger was referred to as the "grandmother" of a man, a bee was called "si hitam manis" (the black sweet).

For some, Dedeng may functions a means of personal entertainment that can be seen during rice planting or harvest season. The participation of community in group activities while singing Dedeng provides them a sense of satisfaction. Therefore, everyone is invited in the activity. This is because they can channel their talents and abilities in the activity of singing Dendeng which gives them satisfaction. In addition, Dedeng as oral tradition can be used to share feelings to others.

Dedeng as an aesthetic presentation can be seen from the participants who participate directly in the activities of cutting down trees, planting rice, and 
at the time when the harvest season arrived. As the activity occured, they use poems spontaneously as many as possible by singing the rhyme and the poem is created instantly with deep meaning. For the ethnic of Malay community in general, the ability to create a beautiful poem in terms of its meaning is an indication of a high social status. For them, sense can be measured by the ability to use and master texts to create poems. The beauty in represents someone's level in a society.

\section{The Types of Dedeng}

Based on the form of usage or presentation, Dedeng is basically divided into several types. , Dedeng which is sung at the time of cutting down trees in order to open a new land of agriculture called Dedeng Mulaka Ngerbah. Second, Dedeng performed at the time of rice seed planting called Dedeng Mulaka Nukal. Both Mulak Ngerbah and Mulaka Nukal become one unity in Dedeng Padang Reba. Third, Dedeng performed at the time of rice is yellow and ready to be harvested called Dedeng Ahoi. Then, Dedeng used for fishing activities in the sea aims to move the dead wind in the middle of the sea.

The Values of Local Wisdom in Dedeng Fifty years ago, in the villages around Stabat city, still we could find offerings in the form of crescent flowers placed under a large old tree that grew near water springs. Since this activity was considered shirk (blapshemy) for some people, the habit of honouring the old tree is now rarely exercised along with the decrease of trees around the springs and the volume of water. Behind the offerings, it is hidden a local wisdom that may not be understood even by the people who did the offerings. Those uncut large trees makes a cool atmosphere around it and preserve the sustainability of the springs.

Our food, breath, house, clothes and all of our equipment are always supported by nature. Our house, for example, consists of sand, stone, cement, and water which come from nature. Similarly, if we explore the source of food we eat, it will lead us to nature as well. Long before modern scientists began to pay their attention to the environment, flora and fauna, and long before they created a new term called eco system, wise people have described and explained human relationships with the environment.
Just keeping the environment clean is not enough, we must preserve nature. We must take care the flora and fauna. In ancient times, humans could not cut down trees. Custom determined the age of trees to cut and it is conducted only for certain purposes. Customary provisions applied, although the tree was located on our own land. We have our own tasks, obligations and responsibilities for the preservation of nature. Do not contaminate water and air. Be careful with energy use. Do not exploit the earth at will. Use the space available, as well as the land wisely.

The previous situation can be seen when the elders, traditional leaders, and the community listen to what the handler tells the nature in the following sentences:

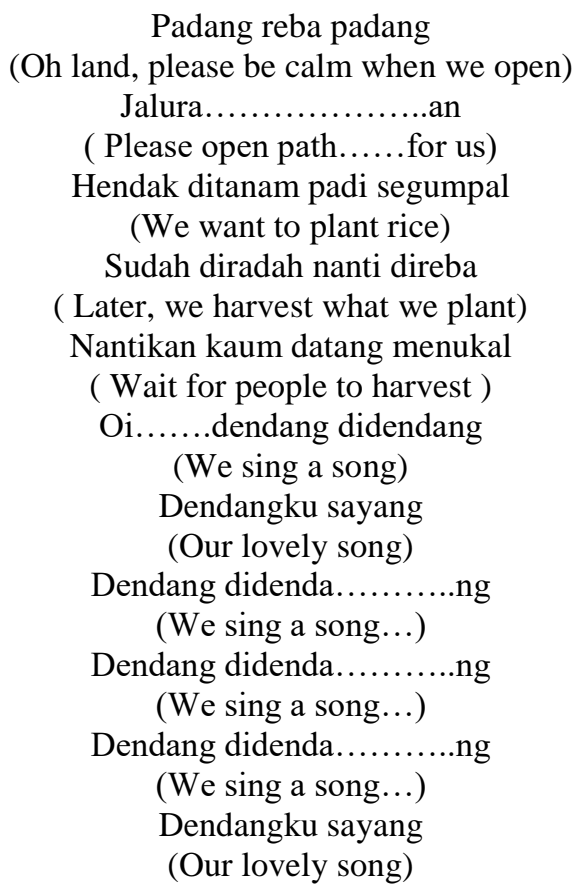

The song then followed by a request in the form of prayer "If we can use this forest as a place for cultivation, please give us a sign so we do not get any obstacles, let us earn a living in this place and give sustenance. Let this axe remains stuck to this wood. But if this tree cannot be cut down, give us a sign so we could move to another place. Gives us a sign of this machete or axe which is off this tree".

This request is a form of respect for nature and supernatural beings. In ancient times, there was a ritual procession called ngerbah hutan (land opening) where people were planning to cut down trees in order to clean up the area that will be used as agricultural land, i.e.by preparing ingredients, potions and a set of tools that were believed to have the power of tuah (luck) means giving offerings to the 
forest ruler (spirits), carrying out the animal slaughter ceremony (chickens, goats, and buffalos), conducting ceremony of tepung tawar (spirit recharging) to rice seed, doing the maintenance and supervision of rice that were starting to fruit, harvesting the rice by cutting them using ani-ani (an instrument to cut rice), and cleaning them together.

Malay agricultural culture is traditional, indigenous and cannot be separated from the beliefs and customs associated with the nature supporting the farm itself. According to custom, when the Malays have seen stars (cosmos) called sandaran lemang, they go down to the fields and start to plant rice (Sinar, 1971: 137). The Malay population in Sumatera Utara (North Sumatera) generally cultivates rice by farming in land area although in some other places (in accordance with residential areas) they plant rice in rice fields.

The text of Dedeng shows that Langkat community has a great respect for nature. After the logging procession, the community gathers and prepares for the next procession of rice cultivation. Before rice cultivation is done, the trees that have been cut down are being left first to decay and not being burned which will lead to other impacts, this process will make the soil more nutritious so that the plant will grow more fertile.

To Care for the Environment When we look closely at the universe, it appears that everything in nature is "organized". It has been arranged. Living things, trees, animals and even rocks, mountains, rivers, seas, all follow a very regular pattern. When we look at the ecosystem around us, we see a harmonious balance. It is wise not to cut trees in water preserved areas. The roots of the tree are able to hold water, so the volume of water in the spring remains. Deforestation makes the volume of the spring decreased. Trees need to be honoured by not cutting them down at will.

In ancient times, when mountains were still shrouded by jungle, the flow of water stopped between the roots of trees and was reluctant to flow down through the bottom. The distinct volume of water found in both rainy and dry season was not significant. Once the shroud of trees is exposed by humans and it is turned into houses and villas, the water will no longer stay in the mountains and it will gather in rivers and cause floods during the rainy season. On the other hand, there will be no water left during the summer because there is no water left in the mountains. Also, the ground soil will be dragged down and deposited in rivers that cause siltation which in turn make floods occurred faster as the river's capacity has diminished. People should pay attention to environmental balance before building villas and houses in a water preserved areas. In addition, global warming can further destroy the balance of nature. The rain becomes much denser and storms occur more frequently while it is drier during the summer. The direction of the wind is always changing so often as a tornado occurs.

Therefore, in the tradition of Dedeng, especially seed dispersal, it is not conducted by using chemicals or pesticides but by using traditional ingredients known as kanji bayam (spinach liquids). This method is used when rice is in the age of 3 months. The tradition combines ancestral traditions with agricultural technology for the prosperity of farmers by praying together in the area of rice crops. The ritual tradition, which is praying ritual to God is performed to protect rice crops from pests / diseases and to get an abundant harvest production. The ritual is usually attended by all farmers after planting rice crops a few weeks earlier. The loss of tradition has not been known for sure, but a strong allegation is the lack of interest of farmers due to the transition of generation. The tradition is considered less useful, just a waste of time and other things. Consequently, at this time only a few parents remember it.

At least there are 17 kinds of herbs used in the ritual but sempilit leaf is the most important. 17 leaves with their stalks are tied together then wrapped by using young banana barks. A small amount of palm tree fibers is also added since it is believed as anti-spirits / evil in the field. After praying together, the farmers spread the leaves to rice fields that have been mixed with water for three days.

This tradition at least reduces natural pollution and supports government programs through the long-established "Go Green" movement. This tradition is still performed by Langkat farmers.

Social Interaction In Dedeng (vocal tradition), indirect communication is performed by using handkerchief (pancapat) sent to get to know each other. In other words, berahoi ceremonies are used by young men and women as a mediation to find a mate. Due to the strict customary system at that time, it was difficult and rare to be able meet women. It occurred as a consequence of a culture of abstinence and forbidding.

The communication in mantra is the interaction of texts and context as semiotically comprehensible symbols of the traditional language signs of the community. The texts of praise or prayer, chanting, humming and mantras are all supernatural communications to the text, context and co-text used 
by the speakers. Communication in the form of listening to the words of others and observing the movements of their bodies, people who are involved in this tradition implicitly relies on visible cues to convey a true picture of the thoughts and their invisible feelings, intentions and so on.

In the context of berahoi local wisdom, the handler communicates to convey his thoughts to others to know the exactness, what kinds of thoughts he wants to convey. The handler then finds visible symbols (including symbols who can be heard), gestures, body language, words, speech etc, which in his opinion can reveal "inner thoughts." When the listener receives the visible symbols, the handler listens carefully what will be said, knows the language used, and also he must observe carefully the symbols used which are not words (such as gestures and flow of the sound). Fourth, the listener must then combines the large number of symbols he receives and converts and convert them into the mind. This is called a "second translation" (Schumacher 1977: 93).

In berahoi tradition, role of shaman or handler is very decisive because they are believed to be able to communicate with the spirit world and the supernatural. Ceremonies which are mythical and mystical can be seen in the ceremony of forest clearing, fields opening, fish holes opening, and ceremonies of 'marine herbs' and rice herbs', and in the tradition of berahoi (rice threshing). Traditionally, this rinjisan potion is believed to contain supernatural powers which will bring good luck to those who are being dirinjisi(sprinkled) in a ceremony. Every ceremony in Malay culture has always been a part of the so-called tepung tawar, which is one of the activities performed to encourage, to give "medicine," or to respect someone-such as before going on pilgrimage, in the ceremony of aqiqah, to welcome the return of someone who was lost before, in the ceremony of Khatanan, marriage, rice planting, and other kinds of similar ceremony. This rinjisan potion is usually used in the event of tepung tawar.

Respect for Women Some of the things found in the traditional values of dedeng are maintaining and nurturing the dignity of women. This can be seen from the place and position of village girls who participated in watching berahoi (an event of Dedeng) tradition . They were placed in a certain room and were not mixed with the young men who were working and were performing berahoi.

In the norms of Malay Langkat community, there is a polite attitude reflected in the separation and sitting system between the group of parents, junior, and girls. Groups of village girls who watched traditional ceremony of berahoi were placed in a certain room in the (loft) houses from where they watched the event.

The position of mothers and the elders was in the gambang (main) room where they entertain themselves after pounding and winnowing certain rice while conveying the message and advice using poems. They perform Dedeng and play the music. Thus, local wisdom is intended as a tool or means to encourage regional development in accordance with supports of the region in solving its regional problems.

Gotong Royong (Mutual Cooperation) Local wisdom referred to as benchmarks and community behavioral foundations containing values and norms of mutual cooperation can be represented through activities of Dedeng tradition named berahoi, lifting and gathering rice on a mat together, threshing rice together,making emping (a type of Indonesian chips, a bite-size snack kripik cracker, made of melinjo or belinjo (Gnetum gnemon)nuts (which are seeds)from young rice, cooking various culinary food to enliven the ceremony and bringing sebambu lemang ( bamboo filled with rice) by each person to be eaten together. Those are pictures of local wisdom of gotong royong represented in the form of berahoi dance done by the youngsters of the community.

In North Sumatra, where the population is very heterogeneous, various tourist attractions are held annually in various regions in order to support the tourism sector. Among these are the Malay Cultural Week, the Great Malay Cultural Festival, the Flower Festival in Tanah Karo, the Yahowu Festival in Nias Islands, the Lake Toba Society Festival in Northen part of Tapanuli, the Rondang Bittang Festival in Simalungun, and many others. Thus, cultural art is the primary means of transmitting and preserving culture in general. In addition, cultural art can also become the basis of the community's economy. Therefore, the preservation of art and culture has become a necessity for people around the world. Cultural art discussed here is a cultural art that is rooted from traditional values.

In addition, the art of culture also reflects traditional values of leadership and it is still relevant to this day and the future. Every culture teaches how to be a leader. These values originate from culture and it is integrated with religious values and religious system. 
Dedeng is a tradition of Malay Langkat which was originally a tradition of calling the dead wind, clearing the forest, planting and threshing rice now has been transformed into the art form of dancing and singing that is popular in Langkat regency. This art is often performed in order to greet regional and state dignitaries, as well as the honorable guests. This change of form makes Dedeng tradition still survive in Langkat society and has become an icon of Langkat district which also become one of tourist attractions in Langkat.

\section{CONCLUSION}

Based on the data analysis, the following conclusions are obtained:

1. Dedeng which was originally a vocal tradition of calling the dead wind for clearing the forest, planting and threshing rice has now been transformed into art form of dancing and singing that become the characteristic of Langkat regency.

2. The values of local wisdom embedded in Dedeng are respect to nature, care to environment, social interaction, respect to women and mutual cooperation.

\section{REFERENCES}

[1] Abdul Kadir, Wan. (1988), Budaya Popular dalam Masyarakat Melayu Bandaran. Dewan Bahasa dan Pustaka:Kuala lumpur.

[2] Alasuutari, Pertti. (2001), Qualitatif Method And Cultural Studies, in Jurnal Ekspresi Seni, June 2012,(14.No.1)

[3] Geertz, Clifford. (1974), The Interpretation Of Culture. Hutchinson \& CO Publisher LTD: London

[4] Manurung,M. Herry. (1995). Dedeng Padang Reba Dalam Kebudayaan Etnis Melayu Langkat:Kajian Etnomusikologis Terhadap Musik dalam Konteks Kebudayaan, Struktur Musik dan Teks. Fakultas Sastra Jurusan etnomusikologi Universitas Sumatera Utara: Medan

[5] Nasution, S. (1982), Metode Research. Jemmars: Bandung.

[6] Pelly, Usman at all. (1986). Sejarah Pertumbuhan Pemerintahan Kesultanan Langkat, Deli Dan Serdang. Departemen Pendidikan Dan Kebudayaan Direktorat Sejarah Dan Nilai Tradisional Proyek Inventarisasi Dan Dokumentasi Sejarah Nasional: Jakarta

[6] Soedarsono,R.M. (2002), Seni Pertunjukan Indonesia Di Era Globalisasi. Gadjah mada University Press: Yogyakarta.
[7] Takari, Muhammad. (1996). Dari kebudayaan Agraris Ke Industri Di Indonesia: Studi Kasus Musik-Musik Etnis Di Sumatera Utara. Program Pascasarjana Universitas Gadjah Mada: Yogyakarta. 